\title{
EXPERIMENTAL PRODUCTION OF ROOFING FELTS
}

\author{
By Merle B. Shaw, George W. Bicking, and O. G. Strieter ${ }^{1}$
}

\section{ABSTRACT}

An investigation is being conducted at the bureau to determine the relative value of different fiber compositions in the life and serviceability of asphalt saturated and coated roofing felts. Experimental felts composed of varying proportions of the usual felt-making fibrous materials, and with a high content of low-grade substitutes not employed commercially in roofing felts, were made for the investigation.

The paper-making materials employed were No. 2 roofing rags, old jute and manila bagging, old newspapers, and finely ground wood sawdust. One felt contained as high as 60 per cent of wood-fiber papers and 30 per cent of sawdust. The paper-making processes consisted of beating the raw materials and converting the prepared stock into a sheet of paper, or felt. The waterleaf felts were made in the semicommercial paper mill of the bureau but were saturated and coated, and thus converted into roofing, in a commercial roofing mill.

Measurements made on the basic papers, the saturated felts, and the finished roofing and analyses of the saturant and of the coating employed are given. To permit comparison of the experimental felts with the commercial product, corresponding data are included for commercial roofing.

The results indicate that relatively large amounts of substitute materials can be used in admixture with rag stock without causing great difficulty in the manufacturing processes. The work at the bureau was on a semicommercial scale, but comparison of the data for the experimental and the commercial felts indicates that the results obtained can be applied directly to commercial practice.

If the durability tests now in progress show that the presence of the substitutes does not decrease the life of the felts in service, the use of these materials in admixture with rag stock would effect considerable economy in the production of roofing felts. The lower cost of the substitute materials and the saving in time and power required for the paper-making process would both contribute materially to reduce the manufacturing costs.

1 Research associate of the Manufacturing and Industrial Research Committee of the Asphalt Shingle and Roofing Institute. 
I. Introduction

II. Description of commercial manufacture of roofing felts__._.

III. Semicommercial paper-making tests_.

1. Paper-making materials_._.

2. Equipment_... 1004

3. Procedure.... 1004

(a) Beating .

(b) Paper-machine operation

IV. Measurements on finished waterleaf-paper felt_.

V. Saturated felts _._. 1009

1. Method of saturating paper felts........... 1009

2. Analysis of saturant used........ 1009

3. Measurements on saturated felts_._. 1011

VI. Asphalt roofing . .

1. Method of applying asphalt coating to saturated felt $\ldots \ldots 1013$

2. Analysis of asphalt coating

3. Measurements on finished roofing felt _. _......... 1013

VII. Commercial roofing felt.

VIII. Summary

\section{INTRODUCTION}

The paper felts used as the base of asphalt roofing materials are made of rags, with or without the addition of substitutes. Owing to the increased cost of rags in recent years, more extensive use of substitute materials in admixture with the rag stock seems inevitable. Accordingly, an investigation to determine the relative value of different fiber compositions on the life and serviceability of roofing materials is being conducted at the Bureau of Standards. The production of the experimental felts described in this publication is a part of that investigation.

Paper felts composed of varying mixtures of the usual felt-making fibrous materials, and with a high content of low-grade substitutes, were needed for the investigation. Because of the high content of substitute materials desired, the felts could not be obtained commercially. Since considerable economy could be effected by the use of the substitutes, if the life of the felts in service would not be materially impaired thereby, it was desired to include papers containing them. The manufacture of the papers was undertaken at the bureau at the request and with the cooperation of the Manufacturing and Industrial Research Committee of the Asphalt Shingle and Roofing Institute. The papers produced were subsequently converted into asphalt roofing in a commercial roofing mill. 


\section{DESCRIPTION OF COMMERCIAL MANUFACTURE OF ROOFING FELTS}

For the reader not familiar with the commercial manufacture of asphalt roofing felts the following brief description is given:

The paper felts are generally formed on a cylinder paper-making machine. ${ }^{2}$ The processes of manufacture are similar to those employed in paper making in general and consist, therefore, of pulping the fibrous material and converting the prepared pulp into a dry, continuous sheet on the paper machine. The felt is impregnated with asphalt by running the sheet through a tank containing asphalt maintained at a high temperature (350 to $400^{\circ} \mathrm{F}$.). The amount of saturant absorbed is dependent on the time the sheet is immersed and the absorptive quality of the felt. After leaving the tank the felt passes around steam-heated rolls which drive in the saturant and remove the excess, so that the surface is dry when the sheet leaves the machine.

The coating is applied by steam-heated coating rolls. Melted asphalt is flowed on the upper side of the sheet and spread uniformly by the upper roll. The excess quantity is allowed to flow into a small tank underneath, where it is picked up by the lower coating roll and spread on the under side of the sheet.

The coated felt while hot is passed under a hopper, where particles of talc, sand, or other granular material are sifted on the surface, and then around cold rolls which firmly press the mineral matter into the hot, soft coating. After cooling, the felt is either wound into rolls or cut into sheets as requirements demand.

Additional information on the properties of asphalt saturant and coating is included in the data on the saturating and coating of the experimental felts.

\section{SEMICOMMERCIAL PAPER-MAKING TESTS}

\section{PAPER-MAKING MATERIALS}

The paper felts must have sufficient strength not to break during the processes of saturation and coating. They must also be sufficiently porous in structure to absorb the proper quantity of the asphalt saturant. The kind and proportion of substitutes that can be employed depend, therefore, on the physical properties of the materials.

The paper-making materials used in the experimental felts were No. 2 roofing rags, old jute and manila bagging, old newspapers, and finely ground wood sawdust.

2 The authors know of only one commercial mill using a Fourdrinier paper machine in the manufacture of roofing felt. The equipment of that mill included the Fourdrinier machine, but not a cylinder machine, before roofing felts were made there, which may account for its use. 


\section{EQUIPMENT}

Although the paper mill of the bureau is equipped for making paper on a semicommercial scale under practical mill conditions, it does not include a cylinder, or felt-making, machine and is therefore not well adapted to making heavy papers of the roofing-felt type. The equipment employed was that in general use in the bureau mill and consisted of a 50-pound wood tub beater, with manganesebronze bars and plate; a 300-pound tile-lined beater, with phosphorbronze bars and plate; a small Jordan refiner, with iron bars; a 4-plate screen; and a 29-inch Fourdrinier paper-making machine, with wire 33 feet long and having two presses, nine 15-inch driers, a small machine stack of 7 rolls, and a reel. ${ }^{3}$

\section{PROCEDURE}

The rags supplied for the tests had been cut into small pieces previous to shipment. The subsequent manufacturing processes consisted, therefore, in beating the raw materials to a pulp and converting the prepared stock into a sheet of paper, or felt.

The strength of the felt depends not only on the physical properties of the raw materials, but also upon the paper-making processes controlling the length of the fibers and the formation of the sheet.

(a) Beating.- The procedure followed in the beating treatment of the different furnishes was established by preliminary experimental tests in the 50-pound beater. The pulps used in the felts described herein, however, were prepared in the 300 -pound beater.

Six beaters of stock were prepared. The furnishes employed were-

No. 1, 100 per cent rag.

No. 2, 60 per cent rag, 30 per cent newspaper, 10 per cent sawdust.

No. 3, 10 per cent rag, 60 per cent newspaper, 30 per cent sawdust.

No. 4, 60 per cent rag, 20 per cent bagging, 20 per cent newspaper.

No. 5, 66.7 per cent bagging, 33.3 per cent newspaper.

No. 6, 100 per cent bagging.

The beating intervals for the furnishes were $5 \frac{1}{2}, 23 / 4,1,5 \frac{1}{6}, 4 \frac{3}{4}$, and $61 / 4$ hours, respectively.

The rags and bagging for each beater were prepared first and the substitute materials were added later. Owing to the small quantity of rags in lot No. 3, the rags were prepared in the 50-pound. beater and transferred to the 300-pound beater for the final beating and mixing. The beating interval given, for this lot is that in the

\footnotetext{
${ }^{3}$ Photographs of the equipment, except the 300-pound beater, are given in B. S. Tech. Paper No. 340, Caroa Fiber as a Paper-Making Material.
} 
larger beater. The rags and bagging of lot No. 4 were treated together.

To produce a felt of open texture with good absorptive quality respecting impregnation with asphalt, vigorous and rapid beating of the stock, with comparatively little hydration, was required. The beater roll was, therefore, lowered as rapidly as the capacity of the motor would permit. The beating progress could doubtless have been accelerated, however, without impairing the quality of the stock.

Prolonged beating causes fibers to disintegrate or split longitudinally into fine fibrillæ. The frictional action in the beating process also has a gelatinizing effect on the surface of the minute fibrous tissues and causes them to become semicolloidal in state. Such stock is said to be "hydrated," "wet," or "slow." Water drains from it slowly on the paper-machine wire, and the finely divided fibers can, therefore, be shaken into a well-felted, smooth-surfaced sheet. The sheet produced has relatively low porosity, however, and, therefore, could not absorb sufficient saturant to give the fibers the degree of protection required for roofing felt.

The rate at which water drains from the pulp is termed "freeness." Measurement of this property at progressive intervals during a beating operation shows the relative "drainability" of the stock and, therefore, serves as an indication as to the progress of the beating. Since all fibers do not hydrate at the same rate, however, the freeness readings for different furnishes do not necessarily gage their comparative fiber lengths. ${ }^{4}$

The fibers in the beater furnishes, previously listed, differ in physical characteristics and, therefore, in rate of hydrating. Consequently, no attempt was made to beat the pulp to a definite freeness reading in the tests described herein. In a mill running on one grade of raw material, however, freeness measurements would doubtless be an effective method of control in maintaining a uniform product. ${ }^{5}$

(b) Paper-Machine Operation.-As previously stated, the bureau paper mill is not equipped with a cylinder machine, the type usually employed commercially for roofing felts, nor is the equipment well adapted to the manufacture of thick papers. Experimental difficulties were experienced in using the small Fourdrinier machine owing to the inadequate capacity of the pump and the drying machinery. The felts made were, however, pronounced very satisfactory by experts of the roofing institute.

4 A more detaiied discussion of the theory of hydration and freeness measurements is given in B. S. Tech. Paper No. 329, Researcb on the Production of Currency Paper in the Bureau of Standards Experimental Paper Mili.

${ }^{3}$ Philip W. Codwise, The Freeness Test in Roofing-Felt Manufacture, Paper Trade J., 85, No. 4, pp. 52-54; July 28, 1927. 
The prepared stock was pumped from the Jordan refiner directly to the paper machine and converted into a continuous sheet. The limited capacity of the pump necessitated reduction of the width of the sheet to 16 inches in order to obtain the weight desired. A 50 -pound felt was originally planned and was made, even with the inadequate pumping facilities, but experimentation showed that a more uniform product could be obtained if the weight was decreased. Accordingly, the weight of the final test felts was reduced to from 40 to 44 pounds.

Difficulty was encountered also in drying the felts. The drying machinery of the bureau's equipment was designed for thin papers, whereas the felts were comparatively thick and held large quantities of water. To overcome the drying difficulty the felts were passed twice over the drying rolls. The moisture content of the finished sheets was about 7 per cent.

\section{MEASUREMENTS ON FINISHED WATERLEAF- PAPER FELT}

The fiber composition of the beater furnish for each machine run and various measurements on the finished waterleaf or unsized sheet are given in Table 1 . The apparatus and methods employed in obtaining the measurements are either described herein or are available in other publications. 


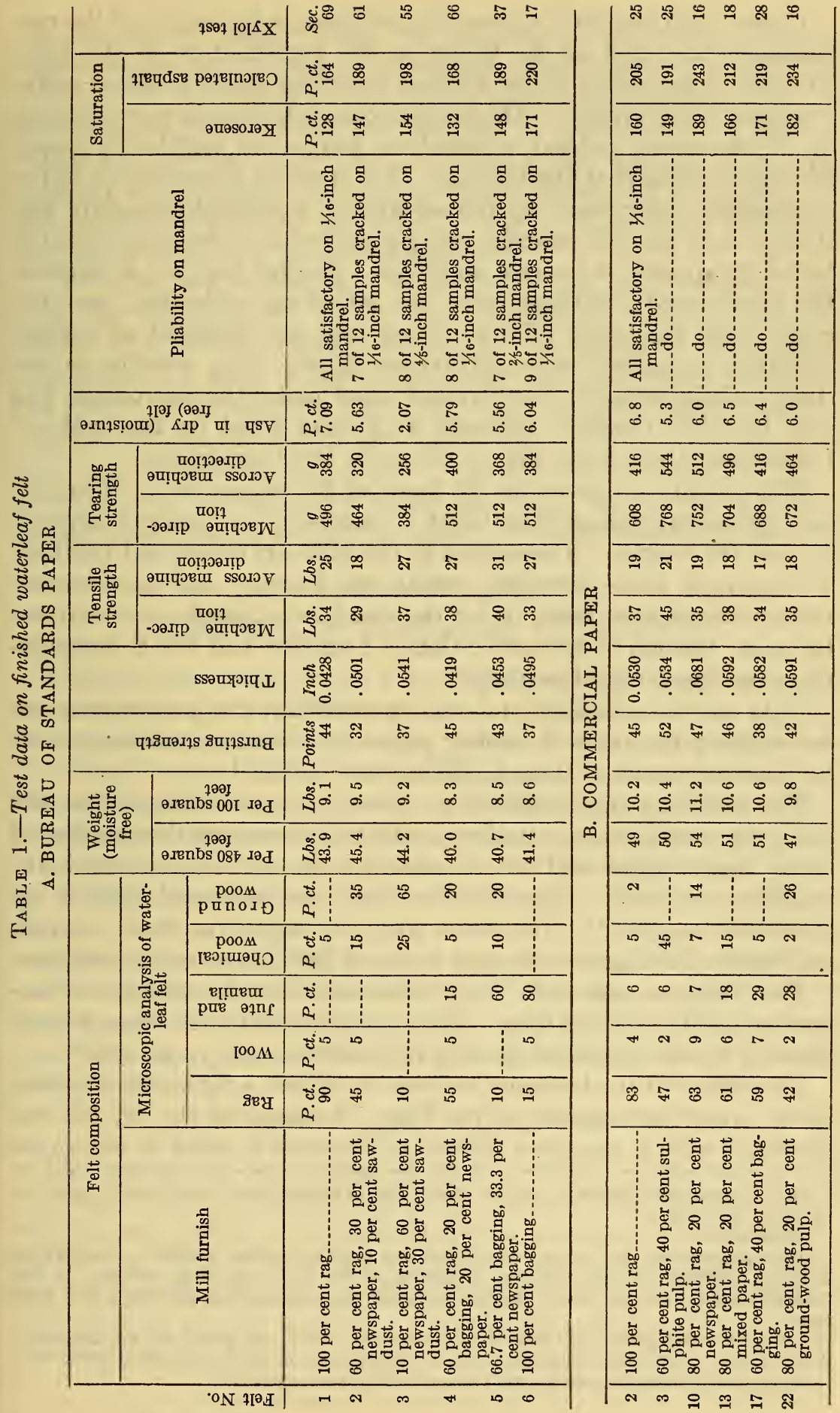


Under "mill furnish" is given the percentages by weight of the raw materials furnished to the beater in the manufacture of the felts. The fiber composition of the finished waterleaf paper is shown under "microscopic analysis." The miscroscopic determinations were made by the dot-count method, of which an adaptation suitable for paper felt was developed at the bureau. ${ }^{6}$ The seeming discrepancies in the composition determined by the laboratory analytical procedure and that given by the mill manufacturing practice can be largely accounted for by the quality of the raw materials. Roofing rags are, in general, the lowest-grade sortings from the mixed-rag collection, and the cotton rags employed (No. 2 roofing rags are classified as cotton) doubtless contained some extraneous fibers. Also sawdust is not clearly distinguishable from ground wood under the microscope and was doubtless therefore reported as ground wood by the analyst. ${ }^{7}$ Considering these facts, the results are in good agreement.

Felt weights are given on the basis of 480 square feet. The felts are customarily spoken of as "light," "medium," or "heavy," depending on the weight. Those given in the table are considered medium. The strength tests - bursting, tensile, and tearing-and the thickness measurements were made under the standard atmospheric conditions for paper testing, 65 per cent relative humidity and $70^{\circ} \mathrm{F}$. temperature, and by standard methods. ${ }^{8}$

Data on the pliability and the saturability also are necessary in determining the value of roofing papers and similar materials, therefore measurements of these qualities were included.

The pliability test consisted in bending 1-inch strips of the dry felt over mandrels at a uniform rate and recording the number of strips that cracked and the diameter of the cylinder on which the cracking occurred. (The pliability test for saturated felts is on moistened samples. ${ }^{9}$ ) The strips were cut lengthwise from the rolls and the the bending was through an arc of $180^{\circ}$ in two seconds of time.

The kerosene and xylol tests were made to determine the saturating quality of the felts. The methods used were those recommended by the Prepared Roofing Association some years ago. ${ }^{10}$

The object of the kerosene test was to obtain a figure for the maximum saturating capacity of the felts. A sample of the dry felt was saturated with a measured volume of kerosene in order to determine

\footnotetext{
6 R. E. Lofton, Determination of the Fiber Composition of Roofing Felts, Paper Trade J., 84, No. 14, pp. 57-58; Apr. 7, 1927.

7 See footnote 6 .

8 These measurements and the ash determination were made by methods described in Paper Testing Methods, published by the Technical Association of the Pulp and Paper Industry, 18 East Forty-first Street, New York, N. Y. The tensile-strength measurements were made on a Scott tensile tester.

- Test same as that specified in United States Government Master Specification No. 295; also same as that described in Asphalt and Allied Substances, by Herbert Abraham, 2d ed., corrected, p. 560; 1920.

${ }^{10}$ Reports of Technical Committee of the Prepared Roofing Association; 1923.
} 
the amount of voids. From the results obtained the theoretical maximum per cent of asphalt saturation of the sheet was computed. The computation involved the weight of the sample, the volume of kerosene the sample absorbed, and the specific gravity of asphalt, which was assumed to be 1.05 . In Table 1 the maximum saturating capacity is reported in two ways, namely, under the first caption as the saturation capacity expressed in terms of kerosene, and under the second caption as calculated asphalt. ${ }^{11}$

The xylol test supplements the kerosene test and has for its purpose the ascertainment of the speed with which saturation takes place. The test consisted in timing the rate of rise of the xylol by capillarity in a strip of the felt, one end of which was immersed in the xylol. Test strips $15 \mathrm{~mm}$ wide and of suitable length were cut lengthwise from the sheet, and pencil lines were drawn across at 1 and $4 \mathrm{~cm}$ from one end of each. The time required for the xylol to rise the $3 \mathrm{~cm}$ intervening between the marks was noted and is reported in the table as the xylol test for the sample under consideration.

\section{SATURATED FELTS}

\section{METHOD OF SATURATING PAPER FELTS}

The felts were saturated by a roofing manufacturer using a regular large-scale production roofing machine. The objective was to keep the saturation around 140 per cent, based on the weight of the felt. To permit comparison of the test specimens, uniformity of saturation and equal amounts of saturant in all the felts were required. Specifications for asphalt roofing require, in general, that the minimum percentage of saturant be 130 for medium-weight felts and 140 for heavy, hence 140 was arbitrarily chosen for the experimental tests.

Because of the different physical characteristics of the substitutes used, the felts differed considerably in saturating capacities. To keep the saturation of the more porous ones down to the percentage specified was, of course, very difficult and, as Table 3 shows, was not always achieved.

\section{ANALYSIS OF SATURANT USED}

The analysis of the asphalt saturant used (for both bureau and commercial felts) is given in Table 2. Most of the tests have been adopted as standard by technical societies, particularly the American Society for Testing Materials and the Prepared Roofing Association, and are described in detail in the publications of those organizations. The methods are also outlined in United States Government Master Specification No. 84.

11 Test is fully described in The Kerosene Test for Roofing Felt, by P. W. Codwise, Paper Trade J., 87, No. 12, p. 60; Sept. 20, 1928. 
TABLE 2.-Analysis of asphalt saturant and coating

\begin{tabular}{|c|c|c|c|c|c|c|c|c|c|c|}
\hline \multirow{2}{*}{. } & \multirow[b]{2}{*}{$\begin{array}{l}\text { Spe- } \\
\text { cific } \\
\text { grav- } \\
\text { ity at } \\
77 / 77^{\circ} \\
\text { F. }\end{array}$} & \multirow[b]{2}{*}{$\begin{array}{c}\text { Melt- } \\
\text { ing } \\
\text { point } \\
\text { (ring- } \\
\text { and- } \\
\text { ball } \\
\text { meth- } \\
\text { od) }\end{array}$} & \multirow[b]{2}{*}{$\begin{array}{c}\text { Duc- } \\
\text { tility } \\
\text { at } 77^{\circ} \\
\text { F. (5 } \\
\text { cm per } \\
\text { min- } \\
\text { ute) }\end{array}$} & \multirow[b]{2}{*}{$\begin{array}{c}\text { Loss } \\
\text { on } \\
\text { heat- } \\
\text { ing } 5 \\
\text { hours } \\
\text { at } 325^{\circ} \\
\mathrm{F} .\end{array}$} & \multirow[b]{2}{*}{$\begin{array}{c}\text { Mat- } \\
\text { ter in- } \\
\text { soluble } \\
\text { in cold } \\
\mathrm{CS}^{2}\end{array}$} & \multirow[b]{2}{*}{ Ash } & \multicolumn{4}{|c|}{ Penetration, in $0.01 \mathrm{~cm}$ units } \\
\hline & & & & & & & $\begin{array}{l}200 \mathrm{~g}, \\
60 \mathrm{sec}- \\
\text { onds at } \\
32^{\circ} \mathrm{F} \text {. }\end{array}$ & \begin{tabular}{|c}
$100 \mathrm{~g}$, \\
5 sec- \\
onds at \\
$77^{\circ} \mathrm{F}$. \\
before \\
heat- \\
ing
\end{tabular} & $\begin{array}{c}100 \mathrm{~g}, \\
5 \mathrm{sec}- \\
\text { onds at } \\
77^{\circ} \mathrm{F} . \\
\text { after } \\
\text { heat- } \\
\text { ing }\end{array}$ & $\begin{array}{l}150 \mathrm{~g}, \\
5 \mathrm{sec}- \\
\text { onds at } \\
115^{\circ} \mathrm{F} .\end{array}$ \\
\hline $\begin{array}{l}\text { Saturant for bureau } \\
\text { felt }\end{array}$ & 1.001 & ${ }^{\circ} C$. & $\underset{48 m}{c m}$ & $\begin{array}{c}\text { Per cent } \\
\quad 0.07\end{array}$ & $\left|\begin{array}{r}P e r \text { cent } \\
0.50\end{array}\right|$ & $\left|\begin{array}{c}\text { Per cent } \\
0.10\end{array}\right|$ & 64.0 & 143.0 & 116.0 & (1) \\
\hline $\begin{array}{l}\text { Saturant for com- } \\
\text { mercial felt-...-. } \\
\text { Coating for bureau }\end{array}$ & 1.035 & 45.9 & (2) & .18 & .20 & .23 & 35.4 & 121.0 & 112.0 & (1) \\
\hline $\begin{array}{l}\text { felt } \\
\text { meating for com- } \\
\text { mercial felt_. }\end{array}$ & 1.034 & 100.9 & 4. 15 & .02 & $\begin{array}{l}.45 \\
.70\end{array}$ & .10 & 11.0 & 16.0 & 14.0 & 37.0 \\
\hline
\end{tabular}

1 Not determined. Too soft.

2 Over 100.

The specific-gravity test is of value for controlling uniformity of supply and for figuring the weight of a given volume. The hydrometer method is generally used to measure the specific gravity, and the standard temperature at which the determination is made is $77^{\circ} \mathrm{F}$. for bituminous materials.

The melting point was determined by the ring-and-ball method, which is essentially as follows: The ring is filled with asphalt, the ball is placed on the center of the upper surface, and the completed unit is suspended at a definite depth in a glass vessel of freshly boiled distilled water at $5^{\circ} \mathrm{C}$. Heat is applied to the bottom of the vessel at such a rate as to raise the temperature of the water $5^{\circ} \mathrm{C}$. each minute. The temperature recorded at the instant the melted asphalt touches the bottom of the vessel is reported as the melting point.

The ductility of an asphalt is defined as the distance to which it will elongate before breaking, when the two ends of a briquet of the material are pulled apart at a specified speed and temperature. When the conditions of test are not specifically stated, the speed and the temperature are understood to be $5 \mathrm{~cm}$ per minute at $77^{\circ} \mathrm{F}$. $\left(25^{\circ} \mathrm{C}\right.$.).

To determine the loss on heating, a sample of the asphalt in a tared container is placed in a constant-temperature oven and maintained at $325^{\circ} \mathrm{F}$. $\left(163^{\circ} \mathrm{C}\right.$.) for five hours. After cooling, the sample is weighed and the loss due to volatilization computed.

The material that does not go into solution by cold extraction with carbon bisulphide is reported as insoluble matter.

Penetration is defined as the consistency of a bituminous material expressed as the distance that a standard needle vertically penetrates a sample of the material under known conditions of loading, time, and temperature. The combinations of these conditions given in the table are all standard. 


\section{MEASUREMENTS ON SATURATED FELTS}

Measurements on the saturated felts are shown in Table 3. The methods of test for the saturated felts, except for water absorption, are fully described in United States Government Master Specification No. 295 and the text, Paper Testing Methods to which reference has previously been made (footnote 8 ). 


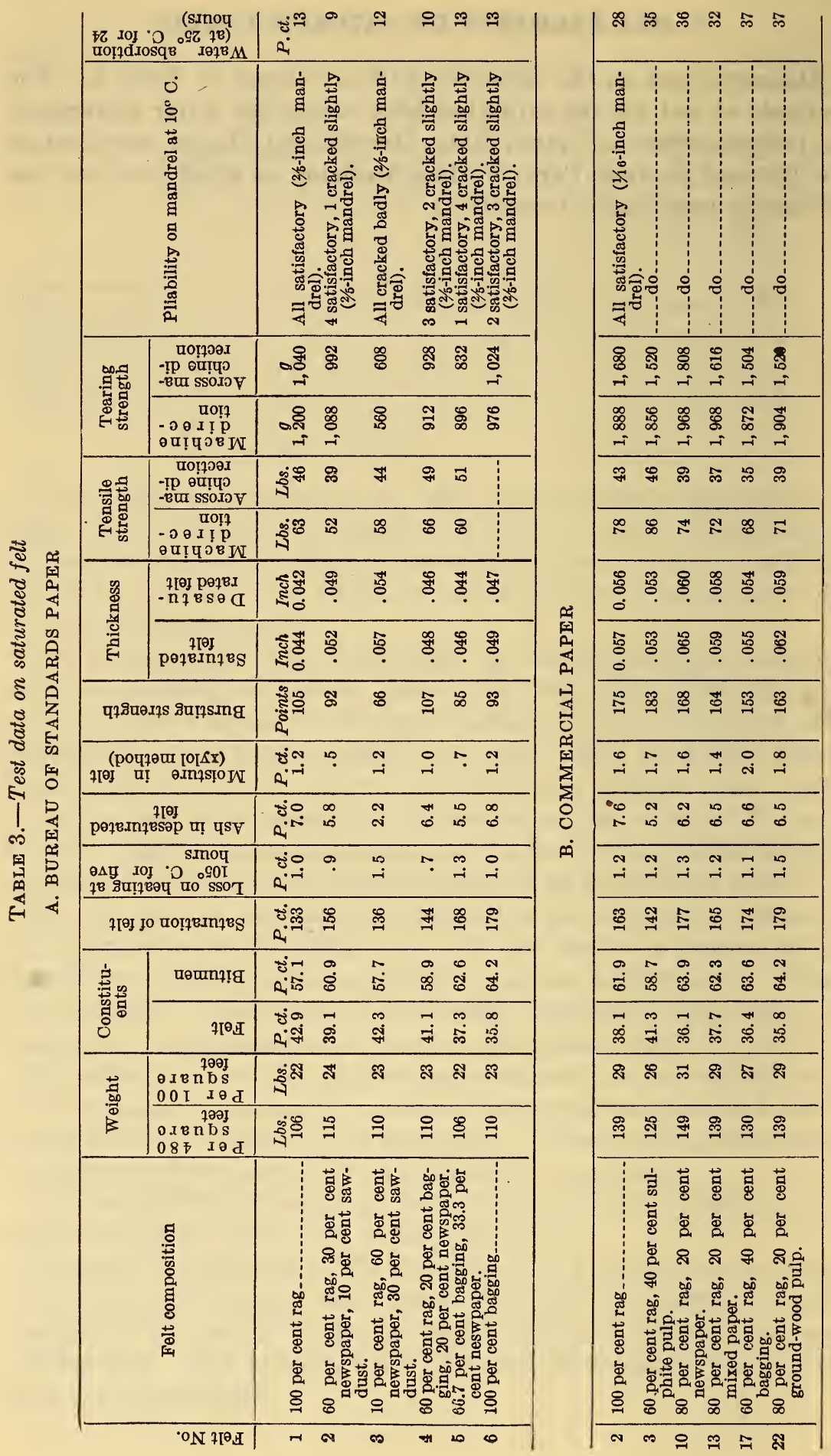


In the water-absorption test a weighed specimen of saturated felt is entirely immersed in water at $77^{\circ} \mathrm{F}$. for 24 hours. A sheet 18 by 18 inches is used in making the test, but since the object of the test is to measure the surface absorption, the treated sheet is trimmed to 12 by 12 inches before its weight is redetermined. Moisture enters more readily through the cut edges of the sheet than through the surface itself, but experience has shown that it does not penetrate more than 3 inches for the period of time immersed in the tests. The reduction in size, therefore, eliminates the effect of seepage through the cut edges. The increase in weight is figured on the basis of the original material.

The tearing tests are new to the roofing industry. They were made with the Elmendorf tearing tester, but the standard design of this instrument is not adapted to heavy material, such as roofing and saturated felts, so a modification had to be made before these materials could be tested. ${ }^{12}$ The modification consisted in doubling the weight of the swinging sector by the addition of a brass plate and multiplying the scale readings by 2 .

\section{ASPHALT ROOFING}

\section{METHOD OF APPLYING ASPHALT COATING TO SATURATED FELT}

The asphalt coating was applied to the saturated felt in a roofing mill using large-scale production coating equipment. The method employed was that described on page 1003.

\section{ANALYSIS OF ASPHALT COATING}

Analysis of the asphalt coating used (bureau and commercial felts) is included in Table 2. The test methods were the same as those described on pages 1009 and 1010.

\section{MEASUREMENTS ON FINISHED ROOFING FELT}

The results of the tests on the finished product are given in Table 4. The methods of test used are those described in United States Government Master Specification No. 214 and the references previously given herein.

12 F. T. Carson and L. W. Snyder, Increasing the Capacity of the Elmendorf Tearing Tester, Paper Trade J., 86, No. 13, pp. 57-60; Mar. 29, 1928. 


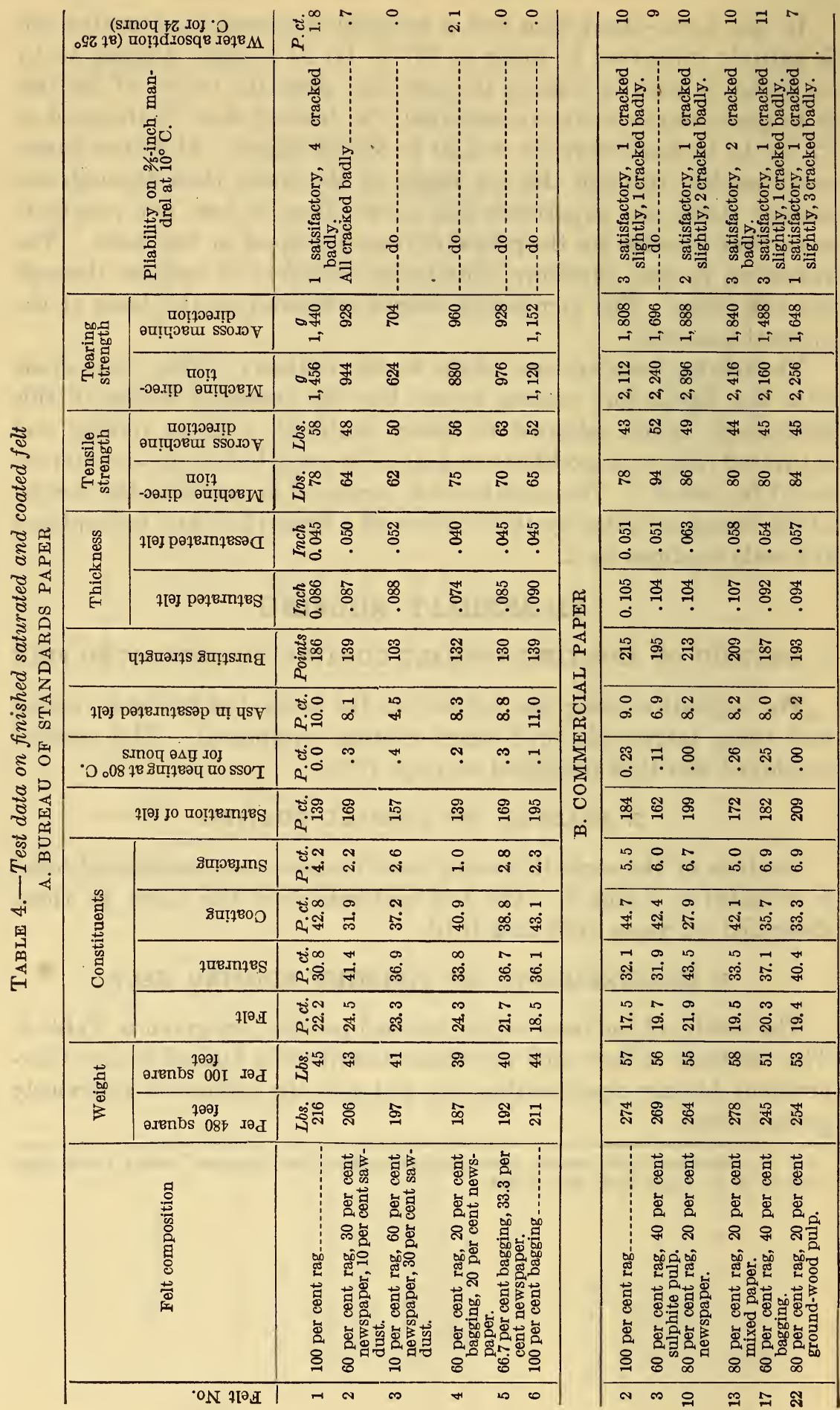




\section{COMMERCIAL ROOFING FELT}

To permit comparison of the experimental felts with those produced commercially, corresponding measurements on commercial felts, produced for experimental purposes, are included in the tables.

\section{SUMMARY}

1. The data given in the tables indicate that the experimental felts made at the bureau on the small Fourdrinier paper machine compared favorably with those produced commercially on a regular felt-making machine.

2. In general, the strength was greater for the commercial than for the bureau felts. In making the comparison, however, consideration must be given to the facts that a smaller percentage of substitutes was included in the commercial felts and that these felts were much thicker, also. The tensile strength of the bureau product was more nearly uniform in the two directions of the sheet.

3. It will be observed that the experimental and commercial felts of similar fiber composition absorbed practically equal amounts of kerosene, and that the same degree of saturation should, therefore, be obtained for both.

4. The comparatively narrow width of the sheet and short length of the roll caused some inconvenience in running the bureau product over the large commercial machines used for saturating and coating the felts. Because of the fineness of the sawdust particles and the possibility that they might contain some resinous materials, it was thought that the felt containing sawdust might char or burn when subjected to the ligh temperature of the saturating bath. No such trouble was noted in the saturating operation, however, and apparently the sawdust remained intact.

5. As would be expected, when large amounts of substitutes were included in the fiber composition the experimental felts proved more brittle than regular roofing.

6. The absorptive quality respecting impregnation with the asphalt was as good for the bureau felts as for the commercial ones. Comparison of the theoretical maximum per cent of asphalt saturation (Table 1) with the actual per cent of asphalt in the saturated felts (Table 3) shows that the felts were all undersaturated. The actual saturation was from 81 to 89 per cent of the theoretical maximum capacity for experimental felts Nos. 1, 2, 4, 5, and 6, and 69 per cent for No. 3. Owing to the small interstices in a felt containing fine sawdust, the saturating rate would, of course, be relatively slow, and for a given time the amount of asphalt absorbed would, therefore, be less. The degree of saturation for the commercial felts was from 73 to 79 per cent.

$47559^{\circ}-29-2$ 
7. Some of the substitutes-for example, bagging and sawdustmade the felts relatively more porous. Such felts absorbed more asphalt and thus afford better protection for the fibers. The greater the percentage of saturant present the more moisture-resistant and, presumably, longer-lived the felts will be in service. If in such cases the initial strength and pliability are sufficient, the felts should prove satisfactory for roofing purposes.

8. The purpose of the investigation was to ascertain whether asphalt roofing felts suffer in serviceability by the addition of substitutes for rag stock. As one of the experimental felts contained as high as 60 per cent of mixed wood-fiber papers and 30 per cent of sawdust, it appears thus far that relatively large amounts of such substitutes can be introduced into the felts without great difficulty in the manufacturing processes. The tests described give considerable information on the behavior of the experimental felts, but the effect of the substitutes on the actual durability of the finished roofing remains to be determined.

9. Additional research on the comparative durability of the felts is in progress. The study includes outdoor exposure of the test specimens and accelerated aging tests in the laboratory. The work is being continued in the chemistry division of the bureau by the research associate of the Manufacturing and Industrial Research Committee of the Asphalt Shingle and Roofing Institute.

10. If the aging tests show that the presence of the substitutes employed does not adversely affect the life of the felts, the use of such substitutes in admixture with rag stock would effect considerable economy. The lower cost of the substitute materials and the saving in time and power required for the paper-making process would both contribute materially to reduce the cost of production.

Washington, February 27, 1929. 